\title{
PHENOTYPES OF EOSINOPHILS IN THE DIAGNOSIS OF ATOPIC BRONCHIAL ASTHMA IN CHILDREN
}

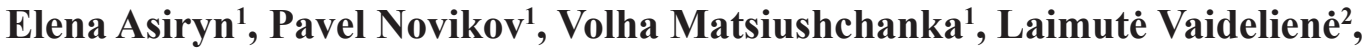 \\ Goda Misevičiūté ${ }^{2}$, Lukas Vaidelys ${ }^{2}$ \\ ${ }^{1}$ Vitebsk State Order of Peoples' Friendship Medical University, Vitebsk, the Republic of Belarus, \\ ${ }^{2}$ Lithuanian University of Health Sciences, Lithuania
}

Key words: bronchial asthma, children, eosinophils, receptors.

\begin{abstract}
Summary
The aim of the research was to study the phenotype of eosinophils in children with atopic bronchial asthma and their role as diagnostic criteria of the disease. Materials and methods. We have examined 130 children aged from 6 to 18 years old with atopic bronchial asthma. The control group consisted of 40 healthy children from 6 to 18 years old, who didn't have allergic diseases. During the research the relative and absolute levels of eosinophils, the level of eosinophils carrying FceRI and FceRII (CD23) - receptors were established.

Results. The relative level of eosinophils in asthmatic children was $6.00 \%$ [3.00; 8.00], the absolute level $-417.00 \mathrm{cells} / \mu \mathrm{L}[232.00 ; 636,00]$, which is significantly higher compared to control group, where the relative level was $2.50 \%[1.00 ; 3.00 \%]$ and the absolute level was 166.50 cells $/ \mu 1$ [86.00; 213.00] $(\mathrm{p}<0.001)$. The level of eosinophils carrying the FceRI receptor was 420,00 cells/ $\mu 1$ [250,00; 660,00], which is significantly higher than in the control group $-200,00$ cells $/ \mu 1[140,00 ; 240.00](\mathrm{p}<0.001)$. The relative level of eosinophils carrying $\mathrm{CD} 23$ receptor on their surface was $62.20 \%[35.40 ; 76.60]$ and the absolute level -223.37 cells $/ \mu 1$ [105.30; 375.24]. The results are significantly higher than those of the control group: $25.45 \%$ [14.30; 30,60] $(\mathrm{p}<0,001)$, and 30,88 cells $/ \mu \mathrm{l}[25,63 ; 42.84](\mathrm{p}<0.0001)$ respectively. It was found in the ROC-analysis that there is high evidence of presence of atopic bronchial asthma if absolute levels of eosinophils carrying CD23 receptor was 73.008 cells/ $\mu \mathrm{l}$ or more or the relative index $-35.10 \%$ and more.
\end{abstract}

Conclusions. The relative and absolute levels of eosinophils, as well as eosinophils carrying FceRI and CD23 receptors are statistically significantly higher in atopic bronchial asthma than in control group patients. Increased number or relative index $(73.008$ cells $/ \mu 1$ or $\geq 35.10 \%$ respectively) of eosinophils carrying $C D 23$ receptors can be considered as a diagnostic criterion of atopic bronchial asthma.

\section{Introduction}

The incidence of bronchial asthma is increasing worldwide in both adults and children $[1,2]$. The diagnosis of the disease in pediatric patients is usually based on clinical symptoms and precise anamnesis. Pulmonary function tests which are commonly used in adults has an age-limit for children and usually are not used for toddlers [3, 4].

The method of skin prick test is used for evaluation of allergies in asthmatic patients [5, 6]. A positive result supports the presence of sensitization to the allergen, however it does not confirm the diagnosis of bronchial asthma. It is well known that there is also a possibility of both false-negative and false-positive results while conducting the test. Therefore, the sensitivity of skin prick is relatively low $[7,8]$.

Currently there is a variety of laboratory methods used in order to confirm allergies and establish the correct diagnosis. For example, one of the most relevant method is the count of total IgE level using enzyme immunoassay [9]. The disadvantage of this method is relatively low diagnostic specificity, because $30 \%$ of patients with atopic diseases tend to have normal total IgE level. In addition, the increase of $\mathrm{IgE}$ level is also associated not only with allergic diseases but also with parasitic invasions [10].

One of the laboratory diagnostic methods most widely used for the diagnosis of allergy is the detection of allergenspecific IgE. However, the detection of $\operatorname{IgE}$ antibodies to a particular allergen does not indicate the responsibility of this 
specific allergen for the clinical symptoms of the disease [11]. It is necessary to compare the clinical features with the results of laboratory and instrumental studies in order to set the final diagnosis. However, even if there is no allergen specific IgE found, the IgE-dependent mechanism of the disease cannot be completely excluded. Local synthesis of IgE and sensitization of mast cells is still possible when specific IgE in the blood serum is negative (for example in allergic rhinitis) [12].

The growth of eosinophils up to $10-20 \%$ is seen in general blood test in the development of allergic diseases, which is called "eosinophilia" [10]. The main proteins contained in the granules of these cells are cytotoxin and neurocytotoxin, which are capable of damaging the body's own cells. Activation of eosinophils is observed with the development of allergic reactions which causes the release of mediators from the granules. In addition, there is an increase of the levels of cytokines such as IL-4, IL-5, IL-10, IL-12, IL-13, GM-CSF and TNF- $\alpha$. Eosinophils also carry receptors for C4, C3, C3b complement components, as well as Fc- fragments of IgG and IgE on their surface. High affinity and low- affinity receptor for IgE could be found on the surface of eosinophils [7]. The most of IgE are connected with the receptors, while the rest circulate in the blood serum, determining the level of total IgE. The allergic process changes the expression of receptors on the cells and the concentration of antibodies in the blood. The development of the pathological process is dependent on the relationship of "Fc-receptor-immunoglobulin", which determines their level in the blood and on cells $[7,13]$.

Considering the immunological mechanisms of bronchial asthma, the study of the phenotype of eosinophils is very perspective and can benefit the diagnosis of the disease as new diagnostic criteria [14]. However, the diagnosis is justified only with the coincidence of clinical and anamnestic data with the results of allergological, immunological and additional methods of examination. Timely diagnosis of bronchial asthma, including its mild forms, that remain undiagnosed in some cases, is important for choosing adequate therapy and achieving good control of the disease [12].

The aim of the research was to study the phenotype of eosinophils in

Table 1. Groups of children included in the survey (Me [25\%; 75\%])

Note: $n$ - is the number of patients in the group

\begin{tabular}{|l|l|l|}
\hline Indicators & Children with asthma $(\mathbf{n = 1 3 0})$ & Control group $(\mathbf{n = 4 0})$ \\
\hline Age $($ years $)$ & $10,00[8,00 ; 14,00]$ & $10,00[7,00 ; 14,00]$ \\
\hline Sex, $\mathrm{m} / \mathrm{f}$ & $90 / 40$ & $26 / 14$ \\
\hline
\end{tabular}

Table 2. Absolute and relative content of lymphocyte's subpopulations in children included in the study

Note: *- significant differences between groups with $p<0.01$; ** - significant differences between groups with $p<0.001 ; * * *$ - significant differences between groups with $p<0.0001$.

\begin{tabular}{|l|c|c|c|}
\hline \multirow{2}{*}{ Indicators } & \multirow{2}{*}{ Units } & \multicolumn{2}{|c|}{ Me [25\%; 75\%] } \\
\cline { 3 - 4 } & & $\begin{array}{c}\text { Children with asthma } \\
(\mathrm{n}=130)\end{array}$ & Control group $(\mathrm{n}=40)$ \\
\hline \multirow{2}{*}{ Eosinophils } & $\%$ & $6,00[3,00 ; 8,00]^{* *}$ & $2,50[1,00 ; 3,00]$ \\
\cline { 2 - 4 } & cells $/ \mu \mathrm{L}$ & $417,00[232,00 ; 636,00]^{* *}$ & $166,50[86,00 ; 213,00]$ \\
\hline FceRI & cells $/ \mu \mathrm{L}$ & $420,00[250,00 ; 660,00]^{* *}$ & $200,00[140,00 ; 240,00]$ \\
\hline CD23 & $\%$ & $62,20[35,40 ; 76,60]^{* * *}$ & $25,45[14,30 ; 30,60]$ \\
\cline { 2 - 4 } & cells $/ \mu \mathrm{L}$ & $223,37[105,30 ; 375,24]^{* * *}$ & $30,88[25,63 ; 42,84]$ \\
\hline
\end{tabular}

children with atopic bronchial asthma and their role as a diagnostic criteria of the disease.

\section{Materials and methods}

We have examined 130 children aged from 6 to 18 years old with atopic bronchial asthma. The diagnosis was established and confirmed on the basis of international recommendations, as well as data of anamnesis, clinical features, results of allergy tests and instrumental studies $[1,12,15]$. The control group consisted of 40 healthy children from 6 to 18 years old who didn't have allergic diseases. During the research the relative and absolute levels of eosinophils, the level of eosinophils carrying FceRI and CD23 receptors were established.

Phenotyping of the cells was carried out on a flow cytometer Cytomics FC 500 (Beckman Coulter Inc., USA) using monoclonal antibodies. The lysis solution OptiLyse $\mathrm{C}$ was used for the lysis of erythrocytes.

Statistical processing of data was carried out using the standard package of applied programs "Statistica 6.0". The Shapiro-Wilk criterion was used to decide on the type of distribution of the quantitative sign. The median and interquartile range were used to describe the characteristic of distribution, which differs from the normal one. Nonparametric methods of statistical research were used: the Mann-Whitney test (for the analysis of differences in two independent groups by the quantitative sign). Differences were considered statistically significant at $p<0.05$. Evaluation of the information significance of the studied indicators in the diagnosis of atopic bronchial asthma was determined with the help of ROC-analysis (Receiver Operating Characteristic) with the creation of characteristic curves of dependence of the sensitivity values on the probability of false positive results and the measurement of the area under the curves. The area under the curve AUC 
(Area Under Curve) was calculated to determine the predictive power of the proposed method. The quality of the model was considered excellent at $\mathrm{AUC}=0.9-1.0$; very good - $\mathrm{AUC}=0,8-0,9$; good - $\mathrm{AUC}=0.7-0.8$; average - AUC $=0,6-0,7$; unsatisfactory $-\mathrm{AUC}=0.5-0.6[16,17]$. The data obtained were analyzed using ROC analysis to determine whether they could be used to diagnose atopic bronchial asthma. Calculation of the indicated parameters and creation of characteristic curves were carried out using the add-in to the Microsoft Excel program package - AtteStat v 12.5 (2011).

\section{Results}

Children in both groups of investigation were comparable by sex and age ( $p>0.05)$ (Table 1$)$.

The relative level of eosinophils in children of the examined group was $6.00 \%[3.00 ; 8.00]$, the absolute level was 417.00 cells/ $\mu \mathrm{L}[232.00 ; 636,00]$, which is significantly higher compared to control group, where the relative level was $2.50 \%[1.00 ; 3.00 \%]$ and the absolute level was 166.50 cells/ $\mu 1$ [86.00; 213.00] $(\mathrm{p}<0.001)$.

The absolute level of eosinophils carrying the FceRI receptor, was 420,00 cells / $\mu 1[250,00 ; 660,00]$, that is significantly higher than the level of the control group, where this figure was 200,00 cells / $\mu 1[140,00 ; 240.00](\mathrm{p}<0.001)$. The level, exceeding the reference values $(<440,00$ cells $/ \mu$ l) was established in $61(46.92 \%)$ patients with bronchial asthma. In this group of children the median value was 660,00 cells / $\mu \mathrm{L}[580,00 ; 840.00]$. In 58 patients a high level of eosinophils was associated with a high level of eosinophils carrying the FceRI receptor.

The number of eosinophils carrying CD23 receptor on their surface was 223.37 cells / $\mu 1$ [105.30; 375.24], relative

Figure 1. The ROC curve according to the data of the absolute level of eosinophils carrying CD23 receptor.

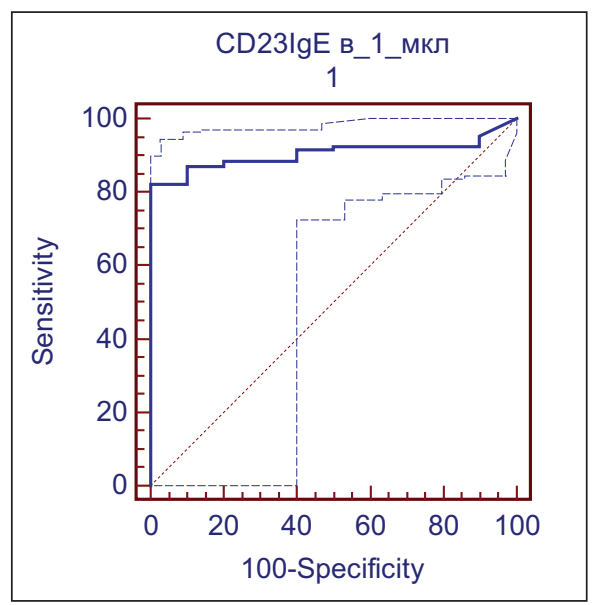

level $-(62.20 \%$ [35.40; 76.60]). The results are significantly higher than those of the control group, where the relative level was $25.45 \%[14.30 ; 30,60](\mathrm{p}<0,001)$, and absolute $30,88$ cells / $\mu 1[25,63 ; 42.84](\mathrm{p}<0.0001)$ (Table 2$)$.

The relative level of eosinophils carrying CD23 receptor exceeded the reference values $(<40 \%)$ in $92(70.77 \%)$ children. The relative index in this group was equal to $70.60 \%[58.25 ; 80.30]$, the absolute level was 289.80 cells $/ \mu 1[172.36 ; 405.31]$. At the same time 56 children with eosinophilia had a high level of this parameter (Table 2).

Among all the studied parameters of the phenotype of eosinophils, those who carried CD23 receptor on their surface appeared to be of the highest diagnostic value. Based on the results of the ROC analysis we obtained the characteristic curve of dependence of the level of eosinophils carrying the CD23 receptor on the presence of atopic bronchial asthma. The optimal "point of separation" for eosinophils carrying CD23 was found to be 73.008 cells / $\mu$ l. At this point, the sensitivity is $82.31 \%$ and the specificity is $100 \%$. Area under curve (AUC) is 0.905 , which indicates high diagnostic efficiency of former model (Fig. 1)

The optimal "point of separation" for the relative level of eosinophils carrying CD23 is $35.10 \%$. At this point the sensitivity was $75.40 \%$ and the specificity was $100 \%$. AUC is 0.859 , which also supports the idea of high diagnostic efficiency of the above-mentioned model (Figure 2).

\section{Results and discussion}

The early diagnosis of bronchial asthma as well as the detection of allergic inflammation of the respiratory tract in children can often be a challenging task even in modern medicine $[9,12]$.

Figure 2. The ROC curve according to the data of relative level of eosinophils carrying CD23 receptor.

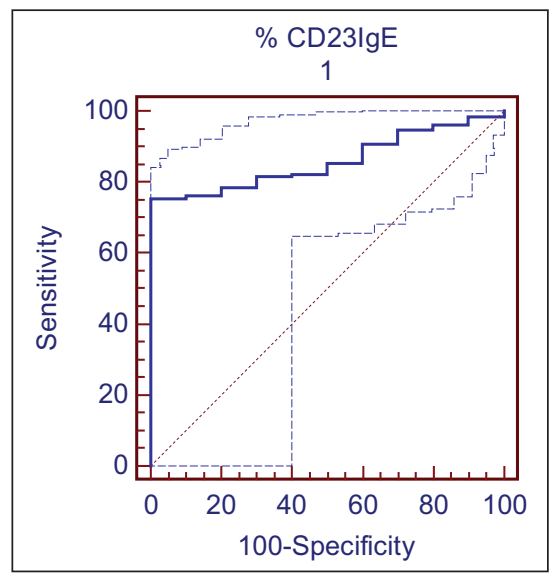


The precise anamnesis and clinical manifestation of the disease are taken into account to set the correct diagnosis. Measuring the lung function in young children for the diagnosis of bronchial asthma is often complicated or even impossible. Moreover, the determination of level of eosinophils is not specific for bronchial asthma due to its dependence on other allergic diseases and parasitic invasions therefore statistical analysis indicates low sensitivity and specificity of eosinophils detection in the diagnosis of bronchial asthma $[7,10]$.

Currently there is a wide range of recommendations, data and indicators on the differential diagnosis of bronchial asthma, which supports the idea that still there is no ideal diagnostic method for the disease [12].

When studying the phenotype of eosinophils in our research an increased level of cells carrying CD23 receptor on their surface was detected. A statistically significant increase of this indicator was registered in the majority of children with bronchial asthma. As a result of the ROC analysis, a threshold level of this indicator was revealed, which allows to confirm the diagnosis of atopic bronchial asthma with proper certainty. Evaluating the results of allergy tests can also help to identify the cause-significant allergen which provokes the development of bronchial asthma in a particular patient. However, it should be remembered that both skin tests and laboratory methods can sometimes demonstrate false positive and/or false negative results. Furthermore, these features don't provide an opportunity to diagnose bronchial asthma in the early stages. Diagnosing bronchial asthma in its mild forms and early stages takes an important place in making the diagnosis and better control of the disease.

The use of our studied method for diagnosing atopic bronchial asthma will promote not only the early and timely diagnosis of asthma, but possible asthma phenotypes as well.

\section{Conclusions}

1. The relative and absolute levels of eosinophils, as well as eosinophils carrying FceRI and CD23 receptors are statistically significantly higher in atopic bronchial asthma than in control group patients.

2. Increased number or relative index $(73.008 \mathrm{cells} / \mu \mathrm{l}$ or $\geq 35.10 \%$ respectively) of eosinophils carrying CD 23 receptors can be considered as a diagnostic criterion of atopic bronchial asthma.

\section{References}

1. Global Initiative for asthma - NHLBI/WHO Workshop Report. National Heart Lung Blood Institute, updated 2016 //www. ginasthma.org.

2. Sizyakina LP, Churyukina EV. Clinical and immunological characteristics of the phenotype of bronchial asthma with the syndrome of secondary immune deficiency. Russian Allergological Journal 2015; 2: 11-4.

3. Ma TT, Zhuang Y, Gong HY, Yii AC, Wang XY, Shi HZ. Predictive value of respiratory symptoms for the diagnosis of pollen-induced seasonal asthma among children and adults in Inner Mongolia. Ther Clin Risk Manag 2017; 4(13): 967-74.

4. Adaeze C Ayuk, Samuel N Uwaezuoke, Chizalu I Ndukwu, Ikenna K Ndu, Kenechukwu K Iloh, and Chinyere V Okoli. Spirometry in asthma care: a review of the trends and challenges in pediatric practice. Clin Med Insights Pediatr 2017; 19(11).

5. Syrov VV. Real possibilities of modern diagnostics of allergy (as review). Allergology and Immunology in Pediatrics 2015; 4(43): 17-29.

6. Cardona V, Demoly P, Dreborg S, Kalpaklioglu AF, Klimek L, Muraro A, Pfaar O, Popov TA, Hoffmann HJ. Current practice of allergy diagnosis and the potential impact of regulation in Europe. Allergy 2018; 73(2): 323-7. https://doi.org/10.1111/all.13306

7. Novikov DK, Novikov PD. Clinical Immunology, Vitebsk. VSMU, 2009.

8. Schou Nielsen J, Meteran H, Ulrik CS, Porsbjerg C, Backer V. Natural history of skin prick test reactivity: A 20-year prospective study of a random population sample of children and adolescents. Ann Allergy Asthma Immunol 2017; 119(2): 184-8. https://doi.org/10.1016/j.anai.2017.05.001

9. Sánchez-García S, Habernau Mena A, Santiago Quirce. Biomarkers in inflammometry pediatric asthma: utility in daily clinical practice. Eur Clin Respir J 2017; 4(1).

10. Drannik GN. Clinical Immunology and Allergology, Moscow. Medical Information Agency, 2003.

11. Nam YH, Lee SK. Comparison between skin prick test and serum immunoglobulin E by CAP system to inhalant allergens. Ann Allergy Asthma Immunol 2017; 118(5): 608-13. https://doi.org/10.1016/j.anai.2017.03.005

12. Chuchalina AG. The national program «Bronchial asthma in children. The strategy of treatment and prophylaxis», 5 th ed., Pererab. and additional. Moscow. Original layout, 2017.

13. Borkowski T.A. Minimal requirements for IgE-mediated regulation of surface Fc epsilon RI. J. Immunol 2001; 167: 1290-6.

14. Novikova VI, Novikov PD, Titova ND. Heterogeneity of allergies in bronchial asthma in children. Vestnik VSMU 2014; 13(4): 110-16.

15. Balabolkin II, Bulgakova VA. Bronchial asthma in children, Moscow. MIA, 2015.

16. Glantz S. Medico-biological statistics, Moscow. Practice, 1999.

17. Zhiltsov IV, Semenov VM, Zenkov SK. Fundamentals of Medical Statistics. Design of biomedical research. Practical guidance, Vitebsk. VSMU, 2014.

18. Asiryn EG, Novikov PD. The method of diagnosis of atopic bronchial asthma in children. Priority reference № a20170121 dated 10.04.17. 
EOZINOFILŲ IR JŲ FENOTIPŲ REIKŠMĖ VAIKU ASTMOS DIAGNOSTIKOJE

E.Asiryn, P.Novikov, V.Matsiushchanka, L.Vaidelienė, G.Misevičiūtė, L.Vaidelys

Raktažodžiai: bronchų astma, vaikai, eozinofilai, receptoriai. Santrauka

Tyrimo tikslas buvo nustatyti tam tikrų eozinofilų fenotipų reikšmę vaikų atopinès astmos diagnostikai.

Metodika. Ištyrėme 130 6-18 m. amžiaus vaikų, kuriems buvo diagnozuota atopinè astma. Kontrolinę grupę sudarè to paties amžiaus 40 sveikų vaikų. Buvo nustatytas absoliutus ir procentinis bendras eozinofilų skaičius, taip pat eozinofilų, nešančių FceRI ir FceRII (CD23) receptorius, kiekis.
Išvados. Bendras eozinofilų skaičius bei eozinofilų, turinčių FceRI ir CD23 receptorius, kiekis atopine astma sergantiems vaikams rastas reikšmingai didesnis nei tiriamiesiems, kurie alerginèmis ligomis nesirgo. Eozinofilų, nešančių savo paviršiuje CD23 receptorius, kiekis buvo reikšmingiausias atopinès astmos diagnostikoje. Didžiausias jautrumas ir specifiškumas rastas tuomet, kai šių ląstelių absoliutus skaičius buvo ne mažesnis, nei 73,008 ląst/ $\mu 1$, o procentinè reikšmė buvo lygi arba didesnè 35,1\%.

Adresas susirašinėti: godamiseviciute@gmail.com

Gauta 2018-12-04 